\title{
The Spatial-temporal Dynamics Analysis of Landscape Pattern and Process in Watershed Scale: a Case Study of 1977-2000 in Siletz Basin, Oregon*
}

\author{
Jiang Hong ${ }^{1,2,3}$, Zhang Yanli ${ }^{4}$, James.R. Strittholt ${ }^{1}$ \\ (1:Conservation Biology Institute, Corvallis, Oregon, 97333, USA; \\ 2:International Institute of Earth System Science, Nanjing University, Nanjing, 210093, P.R.China; \\ 3:Life Science College, Southwest Normal University, Chongqing, 400715, P.R.China; \\ 4:Department of Forest Science, Oregon State University, Corvallis, Oregon, 97333, USA)
}

Abstract: The landscape ecology applied in the analysis and management of watershed is an important issue in modern ecology and geography. Because the population growth and economic development, the pattern and process of watershed influenced strongly by human activity. In this paper, we discussed the spatial-temporal dynamics of landscape pattern and process in watershed scale in central Oregon. Siletz basin is a typical watershed in US Pacific Northwest. The land cover change of Siletz basin between 1977 to 2000 was determined through the satellite remote sensed data application. We used the Landsat MSS of 1977, Landsat TM of 1988 and Landsat ETM+ of 2000 imagery to quantified the forest succession serial (e.g. late serial old and mature conifer forests, early serial young conifer and regeneration forests) and other land covers with high accuracy. The spatial pattern of landscape was analyzed through the multiple pattern metrics, for example, patchiness indices, patch shape complexity indices, and connectivity indices. Based on the spatial databases and literature data, we parameterized the carbon fluxes and stocks information for the forest types and other lands in the US Pacific Northwest, and estimated the carbon fluxes and stock pools and the dynamics from 1977 to 2000 as the anthropogenic disturbance. We revealed the changes of land cover are significant from 1977 to 2000 . The old conifer and mature conifer forests decreased quickly as the clearcut logging. In 1977-2000 periods, the percentage of old conifer and mature conifer area in entire Siletz basin from $23 \%$ and $12 \%$ decreased to $12 \%$ and $7 \%$, respectively. In contrast, the young conifer forest and non-forest land from $24 \%$ and $5 \%$ increased to $43 \%$ and $14 \%$, respectively. The fragmentation of old and mature conifer forest spatial pattern increased quickly as the harvest disturbance between 1977 and 2000. Carbon budget also was found changed significantly between 1977 and 2000. The ecosystem carbon pool decreased from 17640797t to 13405720 t, Net Ecosystem Production

\footnotetext{
* 2003-08-12 received; 2004-09-25 accepted. Corresponding author: Hong Jiang; Phone: 1-541-757-0687; Fax: 1-541-752-0518;
} 
(NEP), an indicator of carbon sink and source, we found the pool of NEP had been changed from 100462 t/a to $76800 \mathrm{t} / \mathrm{a}$ between 1977 and 2000 as the land cover alternated by harvest disturbance.

Keywords: Watershed; remote sensing; disturbance; landscape pattern; carbon fluxes and stocks

\section{Introduction}

Watershed occupied certain area which composite with different ecosystems, for example, aquatic, riparian, and terrestrial ecosystems ${ }^{[1]}$. From the spatial scale and compositions, most watersheds are the typical landscapes; therefore the principle and methodology of landscape ecology properly meet the requirement of watershed analysis and management ${ }^{[2]}$.

Landscapes are dynamic mosaics of natural and human-created patches that vary in size, shape and arrangement ${ }^{[3,4]}$. Monitoring and detecting the change of landscape patterns under disturbance, especially anthropogenesis disturbance is a critical issue for watershed management and sustainable development ${ }^{[1,5]}$. The pattern and process are the fundamental components in the analysis and management of watershed and landscape. Spatial pattern of watershed reflected the historical development and the adaptation for the environmental conditions. The landscape pattern impacts the ecosystem structure and function, also influenced the water and biogeochemical cycling, as well as the natural conservation ${ }^{[1]}$. The fragmentation of landscape pattern results in the decreased size of continuous biotope and decreased the connectivity between populations.

In order to obtain quantitative information on biophysical characteristics of landscape, the remote sensed data area commonly used to determine and monitor the landscape pattern and change ${ }^{[6]}$. The digital nature of land cover information from satellite imagery enables a potentially large number of landscape metrics to be derived. The large area coverage and repeat viewing of remotely sensed data provides information at relatively fine spatial (typically 30 meters) and temporal resolution for mapping the type and dynamics of biotope patches in the landscape $\mathrm{e}^{[7]}$.

Carbon biogeochemical cycles and budget is one of critical ecosystem process in the landscape and watershed. The net flux of carbon between terrestrial ecosystems and atmosphere is uncertain. Mid-latitude forests of the northern hemisphere are currently as a significant carbon sink, but the geographic distribution of the sink and the mechanisms generating it are uncertain ${ }^{[8]}$. In other side, the temperate forests locate in mid-latitude of northern hemisphere had been alternated as heavily human clearcut logging in once continuous cover by mature and old-growth forests. Many forest watersheds and landscapes became highly fragmented and most were deforested. Deforestation has been a source of increasing $\mathrm{C}$ in the atmosphere in the last century $^{[9]}$.

Siletz basin is a typical watershed in central coast Oregon, the watershed covers about $1000 \mathrm{~km}^{2}$, the siletz river across through the watershed(Fig. 1). Since 1970s, many anthropogenesis disturbances happened in this watershed, and alternated the land cover and landscape pattern, convert the carbon sink to sources. As a case study in this paper, we 
quantitatively analyzed the changes of land cover, landscape pattern and carbon budget in 1978, 1989 and 2000 periods of Siletz basin watershed using Landsat MSS, TM and ETM+ satellite imagery and FRAGSTATS spatial pattern analysis method, as well as the carbon fluxes and stocks data. The purposes of this research are to understand the land cover change rate in a typical temperate rain forests watershed and landscape, revealed the landscape pattern dynamics and the impacts on the carbon budget of watershed scale.

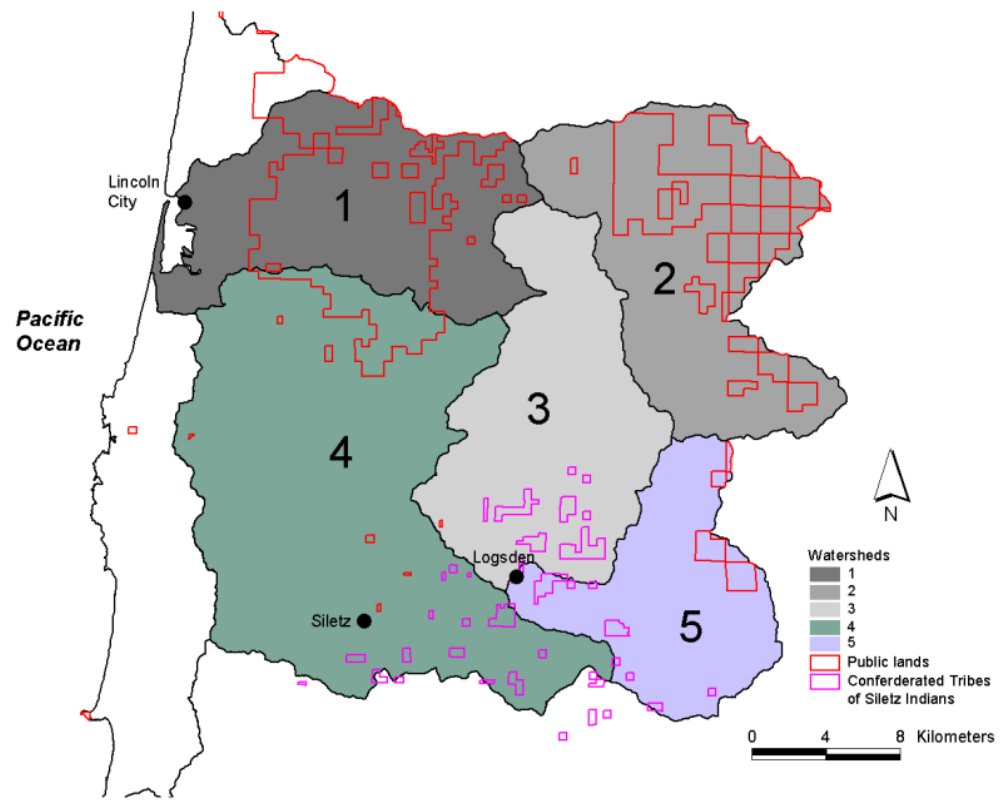

Fig.1 The location of Siletz basin in central coast Oregon, USA.

\section{Methods}

\subsection{Land cover classification using Landsat MSS,TM and ETM+ imagery}

Vegetation classification is the dominant component of land cover mapping in most parts of the world and remote sensing provides the most cost effective means to achieve this goal ${ }^{[10,11]}$. For mid and large areas, Landsat satellite imagery, include Multiple Spectrum Scanner, (MSS), Thematic Mapper (TM) and Enhanced Thematic Mapper Plus (Landsat 7 ETM+), especially Landsat $7 \mathrm{ETM}+$, including one $15 \mathrm{~m}$ panchromatic band and six $30 \mathrm{~m}$ multiple spectral bands, offers reasonably high spatial and spectral resolution upon which a region wide classification can be created. Landsat MSS, TM and Enhanced TM plus (ETM+) satellite imagery was acquired in July 30, 1977, July 21, 1988, and August 2000, path 46 and row 29. The projection system used was Universal Transverse Mercator (UTM) Zone 10; Spheroid was Clarke 1866; and Datum was NAD27. Oregon Digital Ortho Quad (DOQ) images were created by U.S. Geological Survey (USGS) and U.S. Forest Service (USFS) and are in the public domain. The images have been projected into the Oregon Geographic Information Council (OGIC) standard projection (Oregon Lambert). DOQ files, provided in MrSID format, were downloaded from the state of Oregon web site: http://www.odf.state.or.us/gis/doq.html. ERDAS Imagine software was used to 
convert the photos to image file format, and reprojected to the UTM zone 10 projection. A total of 21 DOQ images were used in the project with dates ranging from 1992 to 1995 . The aerial photos used in this project were taken between 1972, 1993 and 1997 and supplied by the Confederated Tribes of Siletz Indians. They were georeferenced to match the DOQ and satellite imagery projection of UTM zone 10. GIS coverage for roads (1:24000) was acquired from the Bureau of Land Management (BLM) to be used in image rectification, as were data layers on cities and towns, tribal ownership (supplied by the Confederated Tribes of Siletz Indians), and elevation in the form of a $30 \mathrm{~m}$ resolution Digital Elevation Model (DEM) acquired from the USGS. The image classification results were field checked in Spring 2002. Forest type, age and other land cover data were collected along with GPS coordinates. Previously published data, for example, Cohen et al ${ }^{[11,12]}$ used Landsat 5 Thematic Mapper (TM) imagery acquired in 1988, produced a vegetation classification for the west Oregon including the Siletz River Basin and published their results in 1995 and 2001, forest age structure was included in this analysis. Their mapped results were used to help inform this effort on imagery.

2.1.1 Image Rectification. The Landsat MSS, TM and Landsat ETM+ imagery was purchased georeferenced to the UTM zone 10 projection. To improve subregional accuracy, the image was rectified using the 1:24000 roads data acquired from the BLM to less than 0.5 pixel root mean-square error (RMSE) using third-order polynomial and resampled to $30 \mathrm{~m}$ pixels using the nearest-neighbor option. Rather than relying solely on RMSE values to assess the quality of the rectification, which relies on a pixel-by-pixel correction, the available road coverage (1:24000) was overlaid on the rectified imagery and visually inspected for quality. Once satisfied with the results, we proceeded to actual image classification. We believe visual analysis with linear features like roads provides a better rectification result than when relying solely on point features (or pixels), which are often difficult to locate on TM imagery.

2.1.2 Optimal Iterative Unsupervised Classification (OIUC) of Vegetation. The objective of vegetation classification using remote sensing is to assign the digital image data (in the form of pixels) into discrete and meaningful categories. A correctly classified image will represent areas of vegetation that share particular spectral characteristics as specified by an established classification scheme ${ }^{[13,14]}$. The method of Optimal Iterative Unsupervised Classification (OIUC) developed for this project is described below. The first step in the OIUC procedure is to build up a useful reference dataset from which to base the satellite image classification. In this case, we combined the DOQ data, Aerial Photos, field survey data and available previously published data on the region ${ }^{[11]}$. These datasets were used to identify the characteristics of the vegetation categories to be discerned from the satellite image. Using supporting imagery and other data is a visual interpretation process ${ }^{[15]}$, which leads to a much better image classification result. We used the reference dataset along with the Landsat MSS, TM and ETM+ false color composite to determine forest classes to be delineated. These false color composites, especially ETM+, are very similar to the overall appearance of aerial photos ${ }^{[14]}$. The main advantage of this approach is that we can use the knowledge of the area to decipher complexities in the landscape that would 
be almost impossible for a computer to interpret in isolation. This type of approach is particularly useful for broad area assessments where classification of individual pixels would not be appropriate ${ }^{[13-15]}$.

For the particular mapping objective in this study area, cover classes were as follows:

1 - Old conifer forest (> 150 years); 2 - Mature conifer forest (50-150 years); 3 - Young conifer forest (10-50 years); 4 - Young regeneration (< 10 years); 5 - Deciduous forest; 6 Semi-open and open forests; 7 - Non-forest; 8 - Water.

The OIUC method, as used in this project, overcomes the problems of parameter variability and mismatching of spectral clusters and thematic classes. In the OIUC method, the homogeneity of a cluster is produced through an iterative approach. In the initial unsupervised classification (ISODATA), 40-60 clusters were produced using the ISODATA command in ERDAS Imagine. These clusters were then matched with reference imagery and data (DOQ images, geo-reference aerial photos, and field notes). The pixels that met homogeneity criteria and provided good matches with classification categories were then recorded into the appropriate vegetation identity. For some classes, the first iteration is adequate to delineate a particular land cover class (e.g., water). Other pixels are more difficult to assign the proper class after the first iteration. For example, pixels influenced by landscape shadows are more difficult to discriminate and require additional runs of ISODATA clustering to break out the various classes of interest.

After the optimal iteration of classification was completed, the results were combined to form the final classified outcome. We merged these files using the OVERLAY function in ERDAS Imagine. The detail description sees Jiang et al. ${ }^{[16]}$.

2.1.3 Accuracy Assessment. Accuracy assessments are essential components of all remote sensing projects. Quantitative accuracy assessments depend upon the comparison of the mapped classes with more reliable reference data. In this project, an independent validation was conducted using the DOQ, aerial photos and ground investigation data. A total of 100-130 random distribution points were assigned and compared. The procedure of accuracy assessment for remote sensing imagery is well described in the ERDAS Imagine Field Guide and reports by Cohen ${ }^{[11]}$ et al. and Wayman ${ }^{[17]}$ et al. The quantitative accuracy assessment includes the creation of an accuracy matrix, error matrix, and Kappa statistic. The classification results reached high accuracy, overall accuracy are $83.18 \%, 82.44 \%$ and $83.38 \%$, respectively (Tab. 1).

\subsection{Spatial pattern analysis}

No single landscape pattern metric captures all aspects of fragmentation; a suite of selected metrics may be useful in interpretation of landscape change and must be carefully considered relative to the type of change (the patches). A common approach in fragmentation research is to calculate a set of metrics that captures a range of fragmentation landscape changes. The set of metrics chosen along with a brief description and algorithms are listed in Tab.2.

The description of landscape pattern requires more than one metrics, so the question now becomes how to select a relevant subset. Determining how many metrics to use and how to combine the metrics so that the results are meaningful and interpretable remains challenging ${ }^{[18]}$. 
The most common metrics applied to analyze forest fragmentation at the class or patch type level include number of patches, mean patch size, patch shape, edge density, mean core area, patch density, fractal dimension, inter-patch distance, and interspersion and juxtaposition. We used the FRAGSTATS spatial pattern analysis program ver. 2.0 (McGarigal and Marks 1995) to calculate the landscape metrics, following metrics were selected in this study: (1) Landscape area, (2) Largest Patch Index (LPI), (3) number of patches (NP), (4) mean patch size (MPS) (ha), (5) Patch Density (PD), (6) Mean Core Area Per Patch (MCA1), (7) Total Core Area Index (TCMI), (8) Area-Weighted Mean Shape Index (AWMSI), (9) Area-Weighted Mean Patch Fractal Dimension (AWMFD), (10) Mean Nearest Neighbor Distance (MNN, meters) (Tab. 1). 10 metrics also classified into four groups to represent the pattern fragmentation metrics (LPI, NP, MPS, PD), interior area metrics (MCA1, and TCMI), patch shape complexity metrics (AWMSI and AWMPDF) and isolation metrics (MNN) of landscape pattern configuration ${ }^{[19]}$.

\subsection{Carbon fluxes and stocks estimation}

There are reports on estimated the carbon fluxes (e.g. NPP) and carbon stocks (e.g. biomass) by remote sensing ${ }^{[6,20,21]}$, however, a lot of ground truth investigation data is the basis to conduct this kind research. For the evaluation of carbon fluxes and stocks in the landscape and regional scale, other common way is to compile published data as parameters in the empirical estimation ${ }^{[8,22]}$. Near by Siletz watershed, there were some data published regard to carbon fluxes and stocks of major forest types, include Douglas-fir, Western Hemlock, Sitka spruce, and Pines (e.g., Ponderosa pine) forests ${ }^{[4,9,22,23]}$. Based on these datasets come from literatures, we compile a datasets, include different vegetation and succession seral in Siletz (Tab. 2). In this table, carbon fluxes have Net Primary Production (NPP), Respiration of heterotrophic (Rh), and Net Ecosystem Production (NEP); carbon stocks have biomass, litter and soil carbon, and ecosystem carbon.

\section{Results}

\subsection{Land cover change}

The vegetation classification results of the Siletz River Basin showed very low proportions of old and mature forests (Tab. 4). Historically, this area was dominated by much older forests (under which species such as salmon evolved) prior to industrial development (Defenders of Wildlife 1998). A very large proportion of the Siletz Basin is young forest, and with over 20 percent of the landscape recent clearcuts or young regeneration. The majority of the older forest cover types are concentrated on the Siuslaw National Forest located primarily in the northwest quarter of the basin and the scattered land holdings managed by the Bureau of Land Management. Older forests on lands owned by the Confederated Tribes of the Siletz Indians are restricted to only a few blocks, and these blocks are isolated and surrounded by very young forestlands (Figs. 2,3,4). 


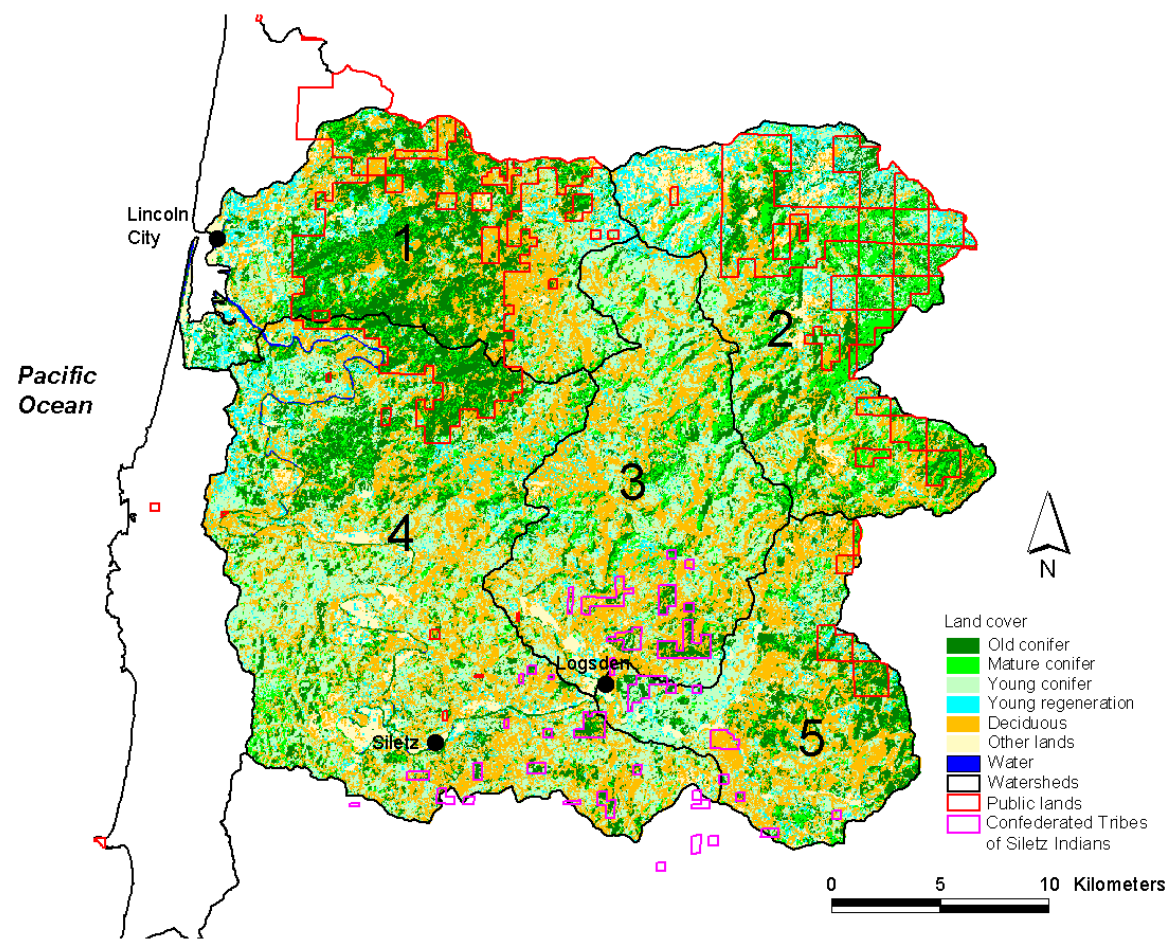

Fig. 2 The Land cover of Siletz basin in 1977, the classification result by Landsat MSS image

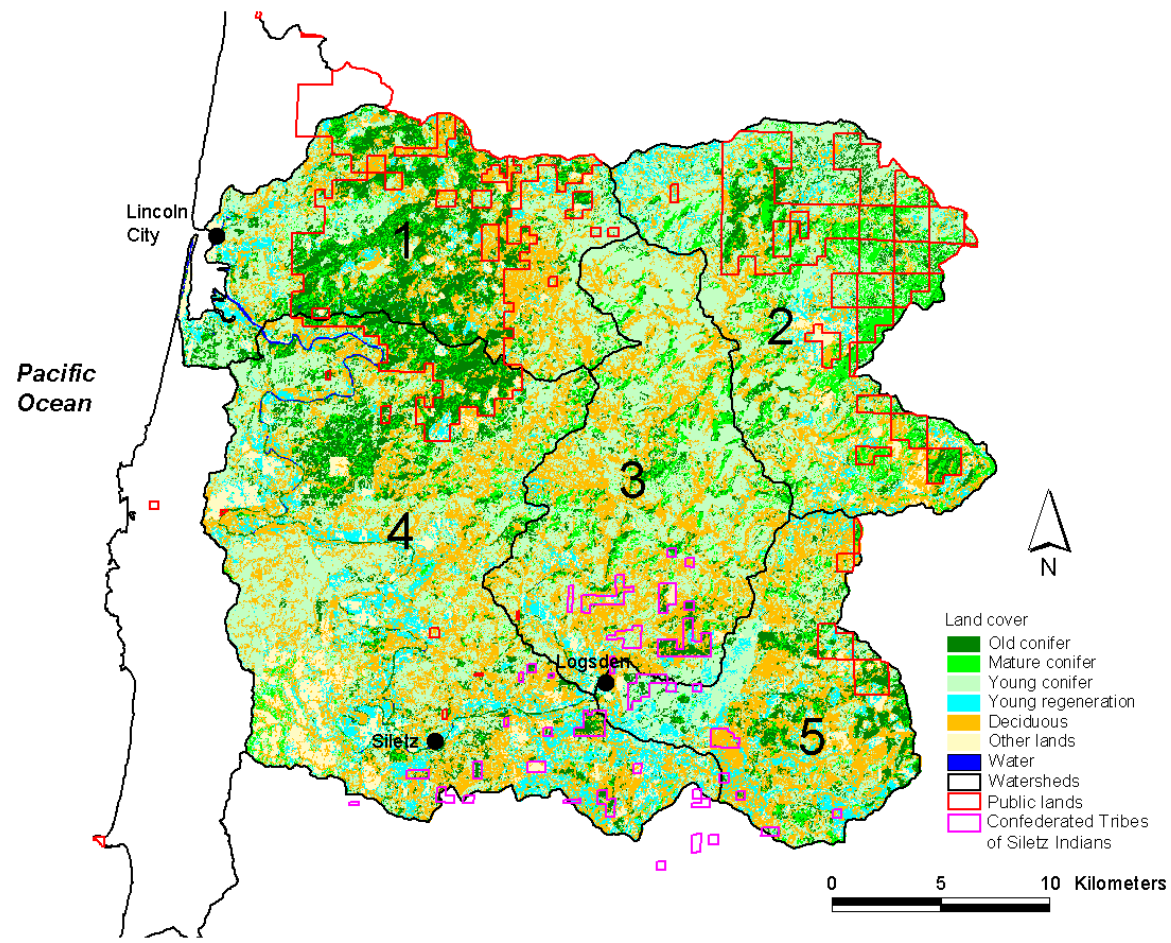

Fig.3 The Land cover of Siletz basin in 1988, the classification result by Landsat TM image 
The changes of land cover are significant from 1977 to 2000 (Figs. 2, 3 and 4). The old conifer and mature conifer forests decreased quickly as the clearcut logging. In 1977-2000 periods, the percentage of old conifer and mature conifer area in entire Siletz basin from $23 \%$ and $12 \%$ decreased to $12 \%$ and $7 \%$, respectively. The young conifer forest and non-forest land from $24 \%$ and 5\% increased to $43 \%$ and $14 \%$, respectively. Deciduous also showed the decline trends, from $29 \%$ in 1977 decreased to $20 \%$ in 2000 .

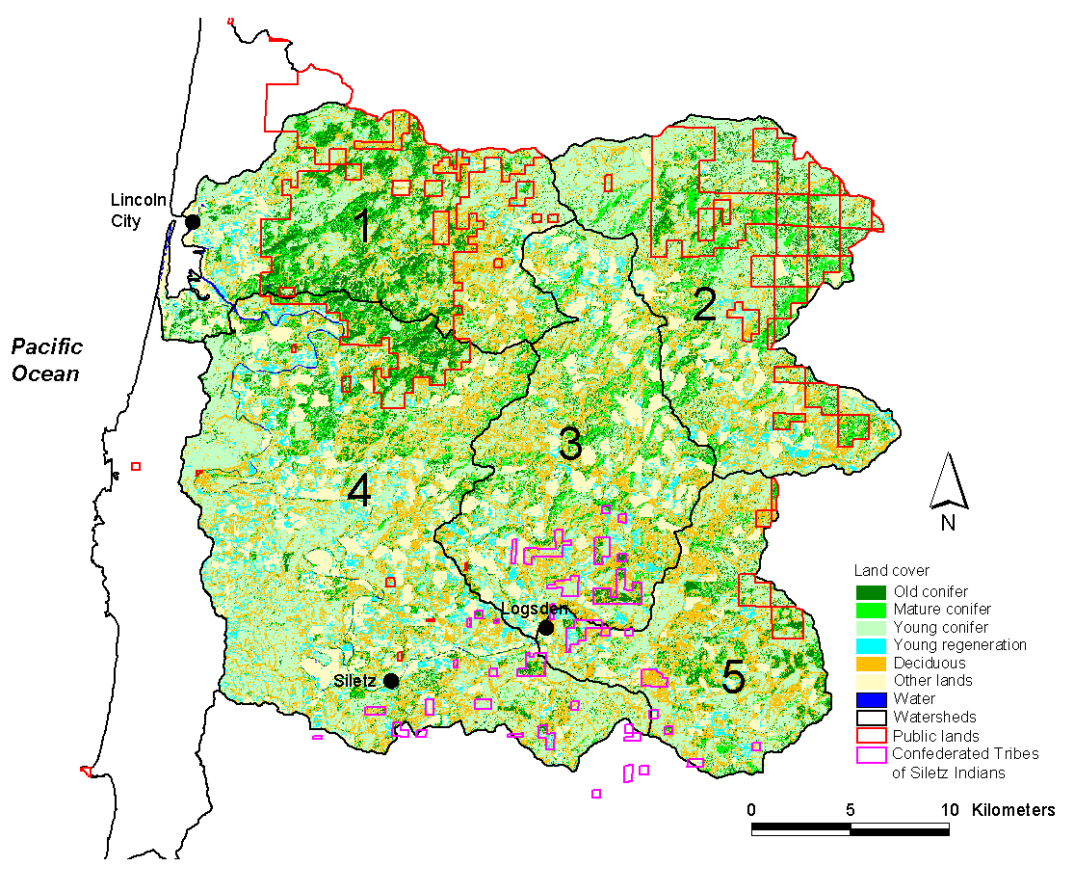

Fig.4 The Land cover of Siletz basin in 2000, the classification result by Landsat ETM+ image

\subsection{Landscape pattern change}

In Pacific Northwest, usually, the old conifer forest consisted of relatively large, continuous patches with very low patch densities. In contrast, the young conifer forest consisted of relatively small patch size and high patch density ${ }^{[19]}$. In Siletz basin, the pattern of old and young forests consistent with the common trends in 1977 (Tab. 4). However, as the harvesting disturbance, the landscape pattern had been changed in 1988 and 2000 periods. In 2000, the old conifer forest showed small patch size, lower large patch index (LPI) and mean core area index (MCA1 and TCAI) and longer mean nearest neighbor distance (MNN), indicating a greater overall level of fragmentation of old conifer forest habitat on this period; the young conifer forest had been changed in different direction, the patch size, LPI and mean core area index increased, indicating these pattern increased the homogeneous. Mature conifer and deciduous forests had similar trend with old conifer forest, also it is not so obvious. The change trend of non-forest land pattern is similar with young conifer forests. The pattern change of regeneration forests is not so regular (Tab. 4). Table 5 summarized the change rate of pattern metrics of different land covers in 1977, 
1988 and 2000 periods.

\subsection{Carbon fluxes and stocks dynamics}

The late seral (old and mature) forests are the carbon pools based on their ecosystem carbon stocks, include living biomass, litter and soil carbon. A lot of carbon storage in aboveground and belowground of late seral forests. In contrast, the young forest, regeneration forest, and non-forest land, they lack of carbon in biomass and litter, and soil carbon is also less than late seral forests, therefore, the carbon pool capacity is much smaller than late seral forest ecosystems, the ecosystem carbon pool decreased from 17640797t to 13405720t between 1977 and 2000 (Tab. 6). Although the NPP of late seral forest usually are lower than young forest, don't have more active ability for carbon sequestration, however, the young forest, regeneration forest and non-forest land have high soil respiration $(\mathrm{Rh})$, release a lot carbon from soil to atmosphere. After balancing the absorb and release, NEP as a synthesis indicator can estimate the net accumulation of carbon, then it can indicate the carbon source and sink role of ecosystem in carbon fluxes. We found the NEP pool of Siletz basin had been changed from 1977 to 2000 as the land cover alternated by harvest disturbance, the NEP pool was decreased from 100462t/a to $76800 t / a$ (Tab. 6).

\section{Discussions}

\subsection{Land cover change in watershed scale}

Watershed is the basic unit in landscape and ecosystems management. A spatially explicit description of land cover, which is generally regarded as the composition and structure of land surface elements, is fundamentally important for resource planning for a wide range of human activities ${ }^{[10,17]}$. As the requirement of forest resources increased following with the human population growth and economic development in Pacific Northwest, especially in coast range, current harvesting intensity stronger and rotation is shorter than history, both in private land and public land. In this study, we found the acceleration period in Siletz basin from 1988 to 2000. The old conifer forest area change rate are $-28.14 \%,-26.84 \%$ and $-47.42 \%$ in $1974-1988$, $1988-2000$, and $1977-2000$ periods, average is $2.06 \%$ per year; the change rate of mature conifer forest area is $-40.88 \%$ in $1977-2000$, average change rate is 1.78 per year (Tab. 4). The average disturbance rate of old and mature forests is $1.92 \%$ per year in the 1977-2000 period(Fig. 5). Because the reforestation, young forests change is positive following with the man-made plantation after harvesting disturbance. The disturbance rate is higher than other nearby area, for example, in a $12000 \mathrm{~km}^{2}$ area of western Oregon, $14.7 \%$ ( $0.7 \%$ per year) of the total forest land was harvested between 1972 and $1993^{[5]}$; In British Columbia interior area of Canada, the decrease of 10.9\% (0.64\% per year) in mature and old conifer forests area between 1975 to 1992. The growth rate in this region is higher than above-mentioned area, it is one of major reasons of the change rate is relatively high. As the western Oregon, close to Cascade, the moisture is lower than Siletz basin, British Columbia of Canada locate in the northern part of temperate rain forests, the production are lower than Siletz. In this region, many private landowners are 
planning for rotations of 55 years, and public lands are planning for 80 years ${ }^{[5]}$.

(a) 1977

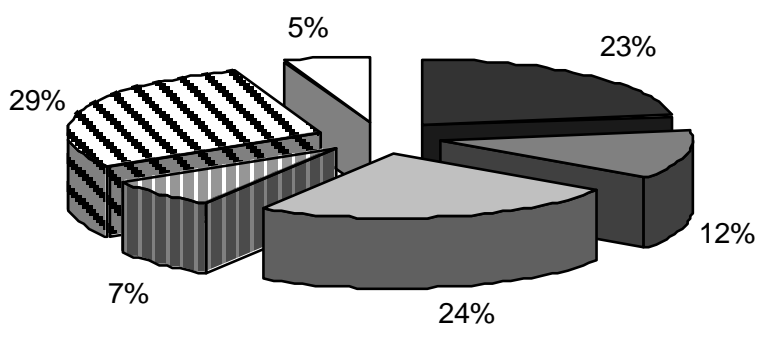

\begin{tabular}{|ll}
\hline Old conifer & $\square$ Mature conifer $\square$ Young conifer $\square$ Regeneration \\
$\square$ Deciduous & $\square$ Non-forest
\end{tabular}

(b) 1998

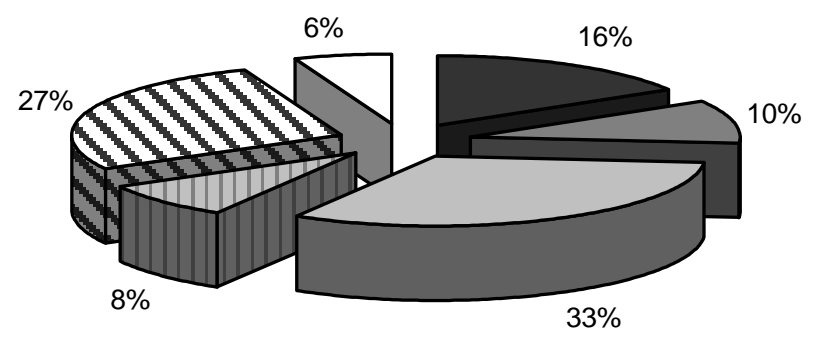

\begin{tabular}{|ll|}
\hline$\square$ Old conifer & $\square$ Mature conifer $\mathbf{\square}$ Young conifer $\square$ Regeneration \\
$\square$ Deciduous & $\square$ Non-forest \\
\hline
\end{tabular}

(c) 2000

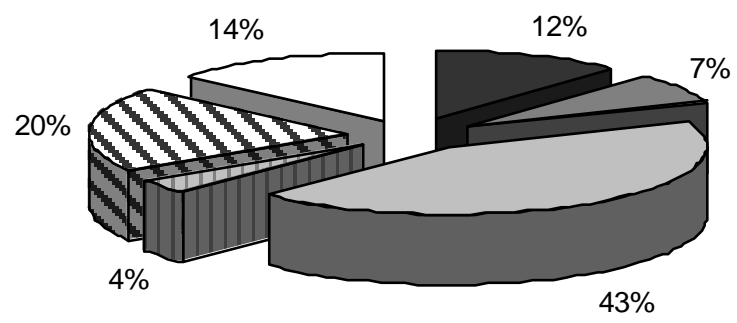

$\begin{array}{ll}\square \text { Old conifer } & \square \text { Mature conifer } \square \text { Young conifer } \square \text { Regeneration } \\ \square \text { Deciduous } & \square \text { Non-forest }\end{array}$

Fig.5 The land cover percentage in Siletz basin in 1977, 1988 and 2000. 
Table 1. The error matrix, user's, producer's, and overall accuracy for the 1977, 1988, 2000 in the Siletz basin

\begin{tabular}{|c|c|c|c|c|c|c|c|c|}
\hline \multirow{2}{*}{$\begin{array}{l}\text { Classified data } \\
\text { Class } \\
\end{array}$} & \multicolumn{8}{|c|}{ Reference data } \\
\hline & Old conifer & Mature conifer & Young conifer & Regeneration & Deciduous & Non forest & Total & User's (\%) \\
\hline \multicolumn{9}{|l|}{1977} \\
\hline Old conifer & 17 & 3 & 1 & 0 & 0 & 0 & 21 & $80.95 \%$ \\
\hline Mature conifer & 3 & 18 & 3 & 0 & 1 & 0 & 25 & $78.26 \%$ \\
\hline Young conifer & 0 & 4 & 25 & 0 & 0 & 0 & 29 & $92.59 \%$ \\
\hline Regeneration & 0 & 0 & 2 & 10 & 0 & 0 & 12 & $83.33 \%$ \\
\hline Deciduous & 0 & 0 & 0 & 1 & 9 & 0 & 10 & $90.00 \%$ \\
\hline Non forest & 0 & 0 & 1 & 0 & 0 & 15 & 16 & $93.75 \%$ \\
\hline Total & 20 & 25 & 32 & 11 & 10 & 15 & 113 & \\
\hline Producer's (\%) & $85.00 \%$ & $72.00 \%$ & $78.13 \%$ & $90.10 \%$ & $90.00 \%$ & $100.00 \%$ & & \\
\hline Overall accuracy (\%) & $83.18 \%$ & & & & & & & \\
\hline $\mathrm{K}$ & 0.78 & & & & & & & \\
\hline \multicolumn{9}{|l|}{1988} \\
\hline Old conifer & 20 & 5 & 0 & 0 & 0 & 0 & 25 & $84.62 \%$ \\
\hline Mature conifer & 4 & 18 & 4 & 0 & 0 & 0 & 26 & $69.23 \%$ \\
\hline Young conifer & 0 & 4 & 25 & 1 & 0 & 0 & 30 & $83.33 \%$ \\
\hline Regeneration & 0 & 0 & 3 & 15 & 0 & 0 & 18 & $83.33 \%$ \\
\hline Deciduous & 0 & 0 & 1 & 1 & 10 & 0 & 12 & $83.33 \%$ \\
\hline Non forest & 0 & 0 & 0 & 0 & 0 & 20 & 20 & $100.00 \%$ \\
\hline Total & 24 & 27 & 33 & 17 & 10 & 20 & 131 & \\
\hline Producer's (\%) & $83.33 \%$ & $66.67 \%$ & $75.76 \%$ & $88.24 \%$ & $100.00 \%$ & $100.00 \%$ & & \\
\hline Overall accuracy (\%) & $82.44 \%$ & & & & & & & \\
\hline $\mathrm{K}$ & 0.78 & & & & & & & \\
\hline \multicolumn{9}{|l|}{2000} \\
\hline Old conifer & 15 & 2 & 2 & 0 & 1 & 0 & 20 & $75.00 \%$ \\
\hline Mature conifer & 0 & 14 & 5 & 0 & 1 & 0 & 20 & $70.00 \%$ \\
\hline Young conifer & 0 & 1 & 28 & 0 & 0 & 0 & 29 & $96.55 \%$ \\
\hline Regeneration & 0 & 0 & 1 & 9 & 0 & 0 & 10 & $81.82 \%$ \\
\hline Deciduous & 0 & 0 & 2 & 0 & 9 & 0 & 11 & $81.82 \%$ \\
\hline Non forest & 0 & 0 & 1 & 0 & 0 & 8 & 9 & $88.89 \%$ \\
\hline Total & 15 & 17 & 39 & 9 & 11 & 8 & 99 & \\
\hline Producer's (\%) & $100.00 \%$ & $82.35 \%$ & $71.79 \%$ & $100.00 \%$ & $81.82 \%$ & $100.00 \%$ & & \\
\hline Overall accuracy (\%) & $83.38 \%$ & & & & & & & \\
\hline $\mathrm{K}$ & 0.79 & & & & & & & \\
\hline
\end{tabular}


Table 2. The metrics of spatial patterns

\begin{tabular}{|c|c|c|c|}
\hline Metrics & Description & Formulas & \\
\hline LPI & $\begin{array}{l}\text { Largest Patch Index. LPI equals the percentage of the landscape that the largest patch comprises. } \\
\text { Number of Patches. }\end{array}$ & $\operatorname{LPI}=\frac{\substack{\mathrm{n} \\
\mathrm{max}\left(\mathrm{a}_{\mathrm{ij}}\right)}}{\mathrm{A}}(100)$ & \\
\hline PD & $\begin{array}{l}\text { Patch Density. PD equals the number of patches in the landscape divided by total landscape } \\
\text { area, multiplied by } 10,000 \text { and } 100 \text { (to convert to } 100 \text { hectares). }\end{array}$ & $\begin{aligned} P D= & \frac{n_{i}}{A}(10,000)(100) \\
& \sum a_{i j}\end{aligned}$ & \\
\hline MPS & $\begin{array}{l}\text { Mean Patch Size. MPS equals the total landscape area }\left(\mathrm{m}^{2}\right) \text {, divided by the total number of } \\
\text { patches, divided by } 10,000 \text { (to convert to hectares). }\end{array}$ & MPS $=\frac{j=1}{n_{i}}\left(\frac{1}{10,000}\right)$ & \\
\hline AWMSI & $\begin{array}{l}\text { Area-Weighted Mean Shape Index. AWMSI equals the average shape index (SHAPE) } \\
\text { of patches, weighted by patch area so that larger patches weigh more than smaller ones. }\end{array}$ & $A W M S I=\sum_{j=1}^{n}\left[\left(\frac{0.25 p_{i j}}{\sqrt{a_{i j}}}\right)\left(\frac{a_{i j}}{\sum_{j=1}^{n} a_{i j}}\right)\right.$ & \\
\hline AWMPFD & $\begin{array}{l}\text { Area-Weighted Mean Patch Fractal Dimension. AWMPFD equals the average patch fractal } \\
\text { dimension (FRACT) of patches in the landscape, weighted by patch area. }\end{array}$ & AWMPFD $=\sum_{\mathrm{j}=1}^{\mathrm{n}}\left[\left(\frac{2 \ln \left(0.25 \mathrm{p}_{\mathrm{ij}}\right)}{\ln \mathrm{a}_{\mathrm{ij}}}\right)\right.$ & $\left.\left(\frac{a_{i j}}{\sum_{j=1}^{n} a_{i j}}\right)\right]$ \\
\hline MCA1 & $\begin{array}{l}\text { Mean Core Area Per Patch. MCA1 equals the sum of the core areas of each patch }\left(\mathrm{m}^{2}\right) \text {, } \\
\text { divided by the number of patches, divided by } 10,000 \text { (to convert to hectares). }\end{array}$ & $\operatorname{MCA} 1=\frac{\sum_{j=1}^{n} a_{i j}^{c}}{n_{i}}\left(\frac{1}{10,000}\right)$ & \\
\hline TCAI & $\begin{array}{l}\text { Total Core Area Index. TCAI equals the sum of the core areas of each patch }\left(\mathrm{m}^{2}\right) \text {, divided by } \\
\text { the total landscape area }\left(\mathrm{m}^{2}\right) \text {, multiplied by } 100 \text { (to convert to a percentage); that is, TCAI } \\
\text { equals the percentage of the landscape that is core area. }\end{array}$ & $\operatorname{TCAI}=\frac{\sum_{j=1}^{n} a_{\mathrm{ij}}^{\mathrm{c}}}{\sum_{j=1}^{\mathrm{n}} \mathrm{aij}^{\mathrm{i}}}(100)$ & \\
\hline MNN & $\begin{array}{l}\text { Mean Nearest Neighbor Distance. MNN equals the sum of the distance }(m) \text { to the nearest patch } \\
\text { of the same type, based on nearest edge-to-edge distance, for each patch in the land-scape } \\
\text { with a neighbor, divided by the number of patches with a neighbor. }\end{array}$ & $M N N=\frac{\sum_{j=1}^{n^{\prime}} h_{i j}}{n^{\prime} i}$ & \\
\hline
\end{tabular}

$\mathrm{A}=$ Total landscape area $\left(\mathrm{m}^{2}\right) . \quad$ aij $=$ Area $\left(\mathrm{m}^{2}\right)$ of patch ij. $\quad \mathrm{n}=\mathrm{ni}$ Number of patches in the landscape of patch type (class) $\mathrm{i}$. $n^{\prime}=n^{\prime} i$ Number of patches in the landscape of patch type (class) i that have nearest neighbors. pij $=$ Perimeter $(\mathrm{m})$ of patch ij. $\mathrm{hij}=$ Distance $(\mathrm{m})$ from patch ij to nearest neighboring patch of the same type (class), based on edge-to-edge distance.

aij $^{c}=$ Core area $\left(m^{2}\right)$ of patch ij based on specified buffer width $(m)$. 
Table 3. The carbon stocks and fluxes of different forest types in PNW

\begin{tabular}{|c|c|c|c|c|c|c|c|}
\hline \multirow[b]{2}{*}{ Vegetation } & \multicolumn{4}{|c|}{ Carbon stocks (Mg C ha" $)$} & \multicolumn{3}{|c|}{ Carbon fluxes (kg C ha-1 $\left.\mathrm{yr}^{-1}\right)$} \\
\hline & Biomass & Litter & Soil C & Ecosystem C & NPP & $\mathrm{Rh}$ & NEP \\
\hline Old conifer & 348 & 69 & 52 & 469 & 3878 & 2878 & 1000 \\
\hline Mature conifer & 180 & 50 & 53 & 283 & 6203 & 4054 & 2149 \\
\hline Young conifer & 58 & 13 & 39 & 109 & 6355 & 4808 & 1547 \\
\hline Regeneration & 9 & 12 & 18 & 39 & 3310 & 5110 & -1800 \\
\hline Deciduous & 43 & 33 & 25 & 100 & 6080 & 4490 & 1590 \\
\hline Non-forest & 4 & 5 & 11 & 19 & 2830 & 4930 & -2100 \\
\hline
\end{tabular}

Table 4. The metrics of landscape pattern in 1977, 1988 and 2000 of the Siletz Basin

\begin{tabular}{|c|c|c|c|c|c|c|c|c|c|c|c|}
\hline TYPE & Area(ha) & LPI & $\mathbf{N P}$ & PD & MPS(ha) & ED & AWMSI & AWMPFD & MCA1 & TCAI & MNN \\
\hline \multicolumn{12}{|l|}{1977} \\
\hline Old conifer & 23222 & 4.27 & 8907 & 2.34 & 2.6 & 44.85 & 14.95 & 1.24 & 1.28 & 15.28 & 95 \\
\hline Mature conifer & 12271 & 0.47 & 13516 & 3.56 & 0.9 & 33.03 & 4.07 & 1.16 & 0.23 & 7.31 & 108 \\
\hline Young conifer & 24087 & 1.81 & 14704 & 3.87 & 1.6 & 59.26 & 11.34 & 1.25 & 0.89 & 13.27 & 76 \\
\hline Regeneration & 7318 & 0.25 & 12249 & 3.22 & 0.6 & 23.85 & 2.75 & 1.12 & 0.06 & 2.82 & 128 \\
\hline Deciduous & 29002 & 1.91 & 11032 & 2.9 & 2.6 & 61.57 & 13.25 & 1.27 & 1.91 & 18.39 & 80 \\
\hline Non-forest & 5547 & 0.21 & 3512 & 0.92 & 1.6 & 11.49 & 3.64 & 1.16 & 1.22 & 19.58 & 155 \\
\hline \multicolumn{12}{|l|}{1988} \\
\hline Old conifer & 16687 & 3.1 & 6953 & 1.7 & 2.4 & 33.28 & 14.4 & 1.25 & 1.08 & 13.76 & 114 \\
\hline Mature conifer & 10109 & 0.44 & 10536 & 2.77 & 1.0 & 26.66 & 4.19 & 1.17 & 0.26 & 8.14 & 119 \\
\hline Young conifer & 32748 & 5.83 & 15332 & 4.03 & 2.1 & 69.64 & 19.72 & 1.3 & 1.9 & 22.43 & 66 \\
\hline Regeneration & 8404 & 0.15 & 13556 & 3.57 & 0.6 & 28.52 & 4.12 & 1.18 & 0.17 & 6.7 & 107 \\
\hline Deciduous & 27505 & 1.63 & 11481 & 3.02 & 2.4 & 62.43 & 13.08 & 1.27 & 1.43 & 15.17 & 79 \\
\hline Non-forest & 5993 & 0.23 & 5747 & 1.51 & 1.0 & 13.74 & 3.64 & 1.16 & 0.91 & 22.34 & 142 \\
\hline \multicolumn{12}{|l|}{2000} \\
\hline Old conifer & 12209 & 2.82 & 6169 & 1.5 & 2.0 & 24.4 & 6.79 & 1.21 & 1.06 & 13.61 & 164 \\
\hline Mature conifer & 7254 & 0.39 & 8824 & 1.65 & 0.8 & 15.68 & 3.12 & 1.16 & 0.23 & 8.78 & 190 \\
\hline Young conifer & 43526 & 6.53 & 15731 & 4.84 & 2.8 & 61.98 & 20.87 & 1.3 & 1.86 & 36.77 & 78 \\
\hline Regeneration & 4083 & 0.13 & 12129 & 3.26 & 0.3 & 12 & 2.57 & 1.14 & 0.16 & 8.15 & 226 \\
\hline Deciduous & 20569 & 1.56 & 11027 & 3.05 & 1.9 & 48.34 & 7.49 & 1.24 & 1.27 & 12.34 & 102 \\
\hline Non-forest & 13785 & 0.28 & 6428 & 1.63 & 2.1 & 14.71 & 3.8 & 1.15 & 1.23 & 51.45 & 234 \\
\hline
\end{tabular}


Table 5. The change rate of pattern metrics in 1974-1988-2000 periods of the Siletz basin

\begin{tabular}{|c|c|c|c|c|c|c|}
\hline Metrics & Old conifer & Mature conifer & Young conifer & Regeneration & Deciduous & Non-forest \\
\hline \multicolumn{7}{|l|}{$1977 / 1988$} \\
\hline Area(ha) & $-28.14 \%$ & $-17.62 \%$ & $35.96 \%$ & $14.85 \%$ & $-5.16 \%$ & $8.04 \%$ \\
\hline LPI & $-27.40 \%$ & $-6.38 \%$ & $222.10 \%$ & $-40.00 \%$ & $-14.66 \%$ & $9.52 \%$ \\
\hline NP & $-21.94 \%$ & $-22.05 \%$ & $4.27 \%$ & $10.67 \%$ & $4.07 \%$ & $63.64 \%$ \\
\hline PD & $-27.35 \%$ & $-22.19 \%$ & $4.13 \%$ & $10.87 \%$ & $4.14 \%$ & $64.13 \%$ \\
\hline MPS(ha) & $-7.94 \%$ & $5.68 \%$ & $30.39 \%$ & $3.77 \%$ & $-8.87 \%$ & $-33.97 \%$ \\
\hline ED & $-25.80 \%$ & $-19.29 \%$ & $17.52 \%$ & $19.58 \%$ & $1.40 \%$ & $19.58 \%$ \\
\hline AWMSI & $-3.68 \%$ & $2.95 \%$ & $73.90 \%$ & $49.82 \%$ & $-1.28 \%$ & $0.00 \%$ \\
\hline AWMPFD & $0.81 \%$ & $0.86 \%$ & $4.00 \%$ & $5.36 \%$ & $0.00 \%$ & $0.00 \%$ \\
\hline MCA1 & $-15.63 \%$ & $13.04 \%$ & $113.48 \%$ & $183.33 \%$ & $-25.13 \%$ & $-25.41 \%$ \\
\hline TCAI & $-9.95 \%$ & $11.35 \%$ & $69.03 \%$ & $137.59 \%$ & $-17.51 \%$ & $14.10 \%$ \\
\hline MNN & $20.35 \%$ & $10.45 \%$ & $-12.45 \%$ & $-16.22 \%$ & $-1.13 \%$ & $-8.22 \%$ \\
\hline \multicolumn{7}{|l|}{$1988 / 2000$} \\
\hline Area(ha) & $-26.84 \%$ & $-28.24 \%$ & $32.91 \%$ & $-51.41 \%$ & $-25.22 \%$ & $130.01 \%$ \\
\hline LPI & $-9.03 \%$ & $-11.36 \%$ & $12.01 \%$ & $-13.33 \%$ & $-4.29 \%$ & $21.74 \%$ \\
\hline NP & $-11.28 \%$ & $-16.25 \%$ & $2.60 \%$ & $-10.53 \%$ & $-3.95 \%$ & $11.85 \%$ \\
\hline PD & $-11.76 \%$ & $-40.43 \%$ & $20.10 \%$ & $-8.68 \%$ & $0.99 \%$ & $7.95 \%$ \\
\hline MPS(ha) & $-17.53 \%$ & $-14.32 \%$ & $29.54 \%$ & $-45.70 \%$ & $-22.14 \%$ & $101.36 \%$ \\
\hline ED & $-26.68 \%$ & $-41.19 \%$ & $-11.00 \%$ & $-57.92 \%$ & $-22.57 \%$ & $7.06 \%$ \\
\hline AWMSI & $-52.85 \%$ & $-25.54 \%$ & $5.83 \%$ & $-37.62 \%$ & $-42.74 \%$ & $4.40 \%$ \\
\hline AWMPFD & $-3.20 \%$ & $-0.85 \%$ & $0.00 \%$ & $-3.39 \%$ & $-2.36 \%$ & $-0.86 \%$ \\
\hline MCA1 & $-1.85 \%$ & $-11.54 \%$ & $-2.11 \%$ & $-5.88 \%$ & $-11.19 \%$ & $35.16 \%$ \\
\hline TCAI & $-1.09 \%$ & $7.86 \%$ & $63.93 \%$ & $21.64 \%$ & $-18.66 \%$ & $130.30 \%$ \\
\hline MNN & $43.61 \%$ & $59.85 \%$ & $17.93 \%$ & $110.33 \%$ & $28.33 \%$ & $64.70 \%$ \\
\hline \multicolumn{7}{|l|}{$1977 / 2000$} \\
\hline Area(ha) & $-47.42 \%$ & $-40.88 \%$ & $80.71 \%$ & $-44.20 \%$ & $-29.08 \%$ & $148.51 \%$ \\
\hline LPI & $-33.96 \%$ & $-17.02 \%$ & $260.77 \%$ & $-48.00 \%$ & $-18.32 \%$ & $33.33 \%$ \\
\hline NP & $-30.74 \%$ & $-34.71 \%$ & $6.98 \%$ & $-0.98 \%$ & $-0.05 \%$ & $83.03 \%$ \\
\hline PD & $-35.90 \%$ & $-53.65 \%$ & $25.06 \%$ & $1.24 \%$ & $5.17 \%$ & $77.17 \%$ \\
\hline MPS(ha) & $-24.09 \%$ & $-9.45 \%$ & $68.91 \%$ & $-43.65 \%$ & $-29.04 \%$ & $32.95 \%$ \\
\hline ED & $-45.60 \%$ & $-52.53 \%$ & $4.59 \%$ & $-49.69 \%$ & $-21.49 \%$ & $28.02 \%$ \\
\hline AWMSI & $-54.58 \%$ & $-23.34 \%$ & $84.04 \%$ & $-6.55 \%$ & $-43.47 \%$ & $4.40 \%$ \\
\hline AWMPFD & $-2.42 \%$ & $0.00 \%$ & $4.00 \%$ & $1.79 \%$ & $-2.36 \%$ & $-0.86 \%$ \\
\hline MCA1 & $-17.19 \%$ & $0.00 \%$ & $108.99 \%$ & $166.67 \%$ & $-33.51 \%$ & $0.82 \%$ \\
\hline TCAI & $-10.93 \%$ & $20.11 \%$ & $177.09 \%$ & $189.01 \%$ & $-32.90 \%$ & $162.77 \%$ \\
\hline MNN & $72.83 \%$ & $76.56 \%$ & $3.24 \%$ & $76.21 \%$ & $26.88 \%$ & $51.17 \%$ \\
\hline
\end{tabular}


Table 6. The changes of the carbon stocks and fluxes in 1977, 1988 and 2000 of Siletz watershed

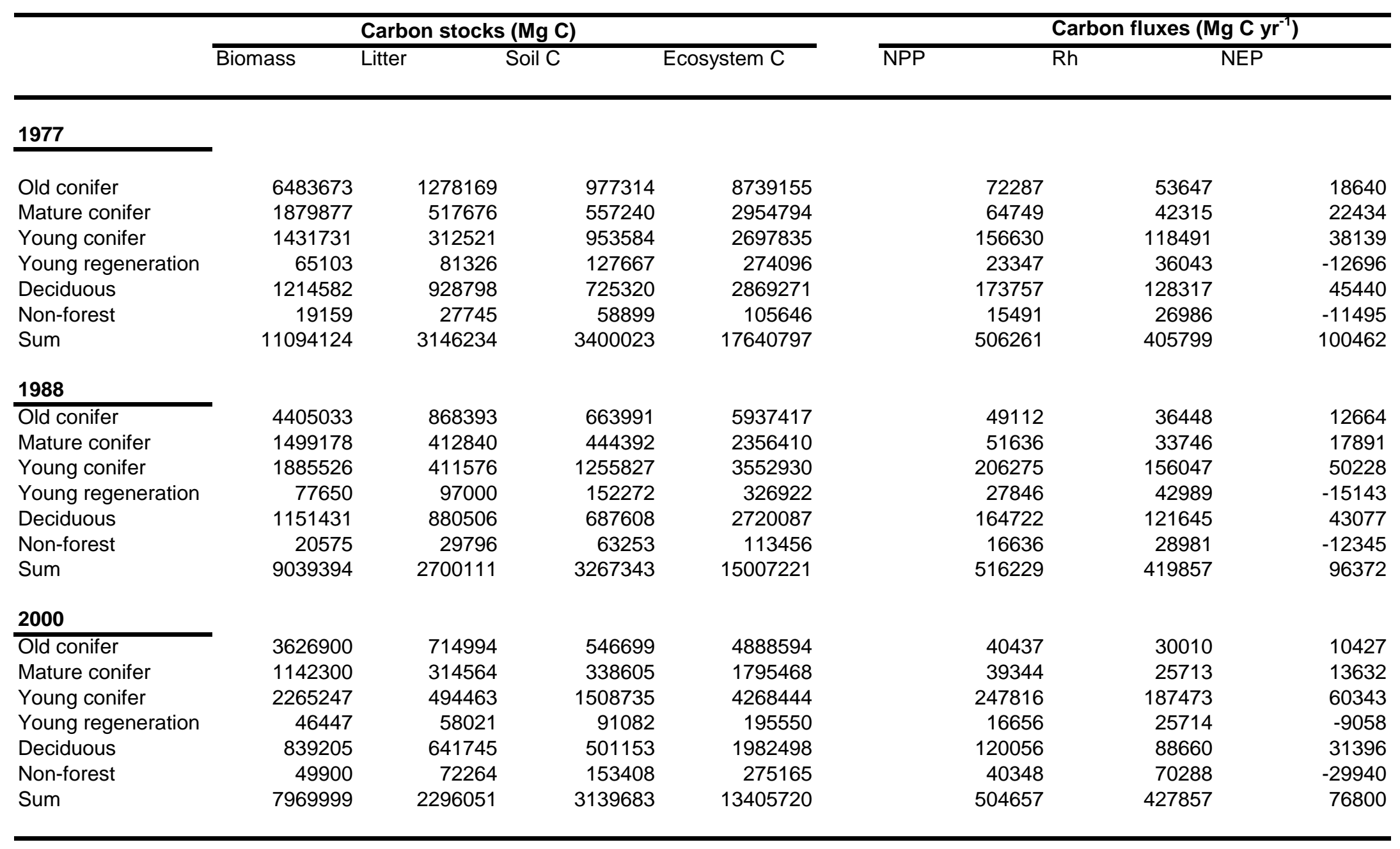




\subsection{Landscape pattern change}

Landscape ecology focuses explicitly upon spatial patterns. Specifically, landscape ecology considers the development and dynamics of spatial heterogeneity, spatial and temporal interactions and exchanges across heterogeneous landscape, influences of spatial heterogeneity on biotic and abiotic processes, and management of spatial heterogeneity ${ }^{[24,25]}$. The quantification of spatial pattern is an area of broadly practical interests ${ }^{[2]}$. Concerns during the last decade over the cutting of old-growth forests in the Pacific Northwest (USA) have focused the need for a better understanding of the effects of forest management upon biodiversity. In this study, the fragmentation analysis suggested that a different pattern of forest disturbance typically occurred at different temporal periods. The fragmentation occurs at many spatial scales and may have a variety of short-term and long-term effects ${ }^{[7]}$. In general, harvesting result in more fragmented landscapes that differ significantly from intact forest in their ecological characteristics. Between 1988 and 2000, the more dispersing clearcut patches results in numerous deleterious fragmentation effects that can greatly influence biodiversity, it also may be strengthen as total area of forest disturbance occurs at high rate.

In Siletz basin, we found younger ones generally replace older forest stands that are logged. If disturbance rates exceed regrowth, forests in the region once dominated by older forests had became increasingly perforated with disturbance and early succession patches. This is a special concern in the US Pacific Northwest where juxtaposition of early- and late-succesional habitats may be facilitating important ecological changes and impacting survival of some species ${ }^{[5,19]}$. Because the pattern of land use can alter both the rate and direction of natural processes, and land-use patterns interact with the abiotic template to create the environment in which organisms must live, reproduce, and disperse, land use refers to the way in which and purposes for which humans employ the land and its resources ${ }^{[1,4]}$. For example, more recent configurations of forest stands of younger age classes have resulted in the expansion of Barred Owl (S. varia) populations that now compete or hybridize with Northern Spotted Owls reducing this species overall fitness ${ }^{[19]}$. Most ecological emphasis on patch size concerns species. Yet, Hobbs (2001) conclude that the effect of habitat fragmentation on ecosystem process. Working in a severely fragmented landscape with scattered, remnant natural vegetation patches, he and his colleagues note major alterations in hydrologic regimes, mineral nutrient cycles, radiation balance, wind patterns, and soil movement. Furthermore, these altered processes change species patterns ${ }^{[1]}$.

\subsection{Carbon budget change}

Landscape ecology is founded primarily on the notion that landscape structure and composition strongly influence ecological processes ${ }^{[2]}$. From this study, we revealed the Siletz basin carbon pool and carbon sink capacity decreased dramatically as the harvesting disturbance. Cohen ${ }^{[26]}$ et al reported the change of carbon source and sink between 1992 and 1991 in western Oregon, they suggested on balance, the 1.2 million ha pilot study area, total net carbon flux during the 19-year period was $+17.5 \times 10^{12} \mathrm{~g}$, a net source to the atmosphere. Their result based on the simulation of modeling. Although our result is not consistent with their conclusion 
regarding the carbon sink switch to the source as harvesting disturbance, however, we also proved that even the reforestation after clearcut logging the old and mature forest, but the young regeneration forest and open land mostly belong to the carbon source, which have highly respiration of heterotrophic. After that, the total carbon sequestration ability decreased hugely in entire basin (Tab. 6). It results in the region carbon budget loss balance, and made more carbon contribution to the atmosphere.

\section{Conclusions}

Siletz basin is a typical watershed in US Pacific Northwest. The spatial-temporal dynamics of landscape pattern and process in watershed scale were studied. Multiple temporal Landsat Satellite remote sensing imagery provided a comparable data resources in the detection of land cover change. The land covers were classified with higher accuracy used the Optimal Iterative Unsupervised Classification (OIUC) method. The spatial pattern and carbon budget were quantified by the FRAGSTAS and literature database. We revealed the changes of land cover are significantly from 1977 to 2000 . The old conifer and mature conifer forests decreased quickly as the clearcut logging. In 1977-2000 periods, the percentage of old conifer and mature conifer area in entire Siletz basin from $23 \%$ and $12 \%$ decreased to $12 \%$ and $7 \%$, respectively. In contrast, the young conifer forest and non-forest land from $24 \%$ and $5 \%$ increased to $43 \%$ and $14 \%$, respectively. The fragmentation of old and mature conifer forest spatial pattern increased quickly as the harvest disturbance between 1977 and 2000. Carbon budget also was found changed significant between 1977 and 2000. The ecosystem carbon pool decreased from 17,640,797 Mg $\mathrm{C}$ to $13,405,720 \mathrm{Mg} \mathrm{C}$, Net Ecosystem Production (NEP), an indicator of carbon sink and source,

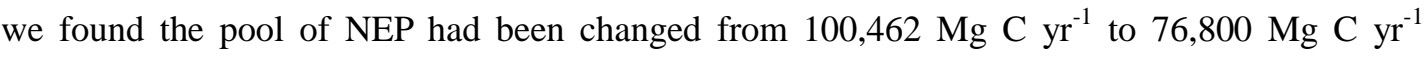
between 1977 and 2000 as the land cover alternated by harvest disturbance.

\section{Acknowledgement:}

The David and Lucille Packard Foundation, and Bureau of Land Management, Department of Interior, USA, and the State Key Fundamental Science Funds of China (grants 2002CB111504) provided funding. We are grateful for free access the auxiliary GIS data layer from USFS, USGS, BLM, Oregon Department of Forestry. We thank free access the FRAGSTAT software, and ERDAS and the Environment Systems Research Institute (ESRI) for their continuing support. We also thank Dr. Dick Warring, R. Robinson, J. Begquist, and N.C. Slosser for their helpful assistance with image processing, field survey and early manuscript preparing.

\section{References}

\footnotetext{
1 Forman R T. Land mosaics, the ecology of landscapes and regions. Cambridge University Press. 2001,632 pp

2 Turner M G, Gardner R H and O'Neill R V. Landscape Ecology in Theory and Practice, Pattern and Process. Springer, New York

and Berlin, 2001:401 pp

3 Turner M G. edit. Landscape Heterogeneity and disturbance. Springer, New York. 1987: 239 pp
} 
4 Turner M G, Wear D N, Flamm R O, Land ownership and land-cover change in the southern Appalachian highlands and the Olympic peninsula. Ecological Application, 1996,6(4):1150-1172

5 Spies T A, Ripple W J, Bradshaw G A. Dynamics and pattern of a managed coniferous forest landscape. Ecological Applications, 1994,4:555-568

6 Wu Y, Strahler A H. Remote estimation of crown size, stand density, and biomass on the Oregon transect. Ecological Applications, 1994,4(2): 299-312

7 Griffiths G H, Lee J, and Eversham B C. Landscape pattern and species richness: regional scale analysis from remote sensing. Int. J. Remote Sensing, 2000,21: 2685-2704

8 Turner D, Gurzy M, Lefsky M A, Tuyl S V, Sun O J, Daly C, Law B E, Effects of land use and fine scale environmental heterogeneity on net ecosystem production over a temperate coniferous forest landscape. Tellus (B), 2002

9 Harmon M E, Ferrell W K, Franklin J F. Effects on carbon storage of conversion of old-growth forests to young forests. Science, 1990,247: 699-702

10 Barrent E C, Curtis L F. Introduction to environmental remote sensing (Fourth Edition). Stanley Thornes (Publishers) Ltd., London. 1999: 457

11 Cohen W B, Maiersperger T K, Spies T A, Oetter O R. Modeling forest cover attributes as continuous variables in a regional context with Thematic Mapper data. International Journal of Remote Sensing, 2001, 22:2279-2310

12 Cohen W B, Spies T A, Fiorella M. Estimating the age and structure of forests in a multi-ownership landscape of western Oregon, U.S.A. International Journal of Remote Sensing, 1995, 16:721-746

13 Lillesand T M, Kiefer R W. Remote sensing and image interpretation (Fourth editions). John Willey \& Sons, Inc. New York, $2000,723 \mathrm{pp}$

14 Jensen J R. Remote Sensing of the Environment: An earth resource perspective. Prentice Hall, New Jersey, 1999 , 544 pp

15 Lachowski H, Maus P. Guidelines for the use of digital imagery for vegetation mapping. USDA, Forest Service, EM-7140-25, $1996,125 \mathrm{pp}$

16 Jiang H, Strittholt J R, Frost P A. The classification of late seral forests in PNW, USA using Landsat ETM+ imagery. Remote Sensing of Environment, (in review). 2003

17 Wayman J P, Wynne R H, Scrivani J A, Reams G. A. Landsat TM-based forest area estimation using iterative guided spectral class rejection. Photogrammetric Engineering and Remote Sensing, 2001, 67: 1155-1166

18 Turner M G, Gardner R H Edit. Quantitative methods in landscape Ecology. Springer, New York. 1991:536 pp

19 Staus N L, Strittholt J R, Dellasala D A, Robinson R. Rate and pattern of forest disturbance in the Klamath-Siskiyou ecoregion, USA between 1972 and 1992. Landscape Ecology, 2002,17:455-470

20 Franklin S E, Lavigne M B, Deuling M J, Wulder M A, Hunt E R Jr. Landsat TM derived forest covertypes for modeling net primary production. Canadian Journal of remote sensing, 1997,243-251

21 Steyaet L T, Hall F G, Loveland T R. Land cover mapping, fire regeneration, and scaling studies in the Canadian boreal forest with 1 km AVHRR and Landsat TM data. Journal of Geographysical Research, 1997,102,D24, 29581-29598

22 Law B E, Sun O J, Campbell J, Tuyl S V, Thornton PE. Changes in carbon storage and fluxes in a chronosequence of ponderosa pine. Global Change Biology, 2003,9: 510-524

23 Turner D P, Cohen W B, Kenedy R E. Alternative spatial resolutions and estimation of carbon flux over a managed forest landscape in western Oregon. Landscape, 2000, 15:441-452

24 Risser P G, Karrr J R, Forman R T T. Landscape Ecology: directions and approaches. A workshop held at Allerton Park; County 
Illinois, 1984, 16

25 Odin C D, Jiang H, Strittholt J R, Frost E J, DellaSala D A. Fire history and severity patterns and forest management in the Klamath National Forest, Northwestern California, USA. Conservation Biology (in press). 2003

26 Cohen W B, Harmon M E, Wallin D O, Fiorella M. Two decades of carbon flux from forests of the Pacific Northwest, estimate from a new modeling strategy. Bioscience, 1996,46 (11): 836-844

\title{
集水区尺度景观格局与过程的时空动态分析：美国俄勒冈州
}

塞勒支盆地 1977-2000 年的变化

\author{
江洪 ${ }^{1,2,3}$ ， 张艳丽 ${ }^{4}$, James, R. Strittholt ${ }^{1}$
}

(1:美国保护生物学研究所, 俄勒冈州科瓦立斯市, 97333; 2: 南京大学国际地球系统科学研究所, 南京, 210093;

3:西南师范大学生命科学学院, 重庆,400715; 4:美国俄勒冈州立大学森林科学系,俄勒冈州科瓦立斯市, 97333)

\section{提要}

在集水区尺度利用景观生态学的原理进行分析和管理是现代生态学与地理科学的一个重要课题. 在 人口增长和经济发展的压力下, 集水区的格局和过程已受到人类活动越来越强烈地干扰. 赛勒支盆地是一 个典型的美国太平洋西北部沿海地区的集水区，本文以此为例，研究了美国俄勒冈州中部集水区尺度的景 观格局和过程在人类活动干扰下的时空动态. 通过卫星遥感影像的应用, 我们对 1977 年到 2000 年间赛勒 支盆地土地覆盖的变化进行了检测. 我们用陆地资源卫星 1977 年的多光谱影像 (MSS), 1988 年的专题影 像 (TM), 2000 年的增强专题影像（ETM+）高精度地定量分析了森林演替系列（如，演替后期的老针叶 林和成熟针叶林，演替前期的年轻针叶林，以及更新的幼林）和其它土地覆盖类型的变化. 景观的空间格 局通过多种格局指数，例如，缀块指数、缀块形状复杂性指数、以及连接指数等进行了分析. 同时，基 于美国太平洋西北部主要森林类型和其它土地覆盖类型碳通量和碳咜量的空间数据库和文献资料, 我们对 1977-2000 年赛勒支盆地中的碳库及其在人类活动干扰下的变化作了测定. 研究结果揭示出, 因为森林皆 伐, 老针叶林和成熟针叶林在 1977-2000 年间显著地减少, 分别由占整个盆地土地覆盖面积的 23\%和 12\%， 减少为 $12 \%$ 和 $7 \%$; 与此相反, 年轻针叶林和无林地则分别从 $24 \%$ 和 $5 \%$ 增加为 $43 \%$ 和 $14 \%$. 同时, 因为 采伐等干扰，留存的老针叶林和成熟针叶林空间分布格局的破碎度也迅速增加. 集水区的碳收支在 1977-2000 期间发生了巨大的变化. 在收获干扰的压力下，在 1977-2000 年间, 整个集水区的生态系统碳 陉量从 17640797t 减少到 13405720t; 净生态系统生产力 (Net Ecosystem Production, NEP) 由每年 100462tC 减少为每年 76800tC.

关键词：集水区, 遥感, 干扰, 景观格局, 碳通量和拒量 